\title{
福井県浜住海岸の地形変化予測と養浜効果検討 \\ Prediction of Bathymetric Changes of Hamaju Coast in Fukui Prefecture and Effect of Beach Nourishment
}

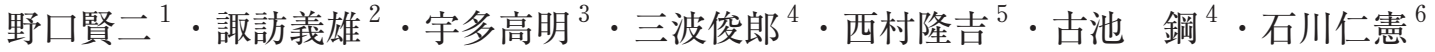 \\ Kenji NOGUCHI, Yoshio SUWA, Takaaki UDA, Toshiro SAN-NAMI, Takayoshi NISHIMURA \\ Kou FURUIKE and Toshinori ISHIKAWA
}

\begin{abstract}
On the Hamaju coast in Fukui Prefecture, beach changes were triggered by large-scale land reclamation and the construction of port breakwater due to their wave sheltering effect. Bathymetric changes were investigated using the past aerial photographs and bathymetric survey data. The effect of beach nourishment using beach materials composed of various grain sizes was predicted by the contour-line-change model considering grain size change, as a soft measure against beach erosion. It is concluded that beach nourishment using coarse sand deposited offshore of the Kuzuryu River is most effective.
\end{abstract}

\section{1.はじめに}

防波堤や埋立地など波の遮蔽構造物が造られると周辺 の波浪場が変化し, 波の遮蔽域の外側から内側へと沿岸 漂砂が生じ，遮蔽域の外側では侵食が進む。このような 場合，従来の対策では侵食域に離岸堤または人工リーフ が設置されることが多いが，設置箇所ではある程度まで 侵食が抑えられるとしても，その隣接域で侵食が進むと いう悪循環がしばしば起こる。このような悪循環を防止 するには，養浜による対策が有効と考えられる。しかし， それを実現するには，投入土砂の質と量を様々変えた場 合の効果を定量的に示すことが求められる．福井県の浜 住海岸では, 図-1に示すように過去に福井港の埋立地が 造成されるとともに，南端の鷹巣港に防波堤が伸ばされ た結果上記の地形変化が起き, 中央部では侵食が進んだ ため 15 基の離岸堤が設置された（宇多ら, 2007). 一方, 当海岸は鷹巣海水浴場としても知られているが, 海水浴 の利用上離岸堤が障害となったため 5 号離岸堤の人工リ ーフ化が進められた。しかし人エリーフ化とともに波浪 の侵入度が増し, その背後で汀線が再び後退するという 事態も起きている. 本研究では, このような海浜変形が 起きた浜住海岸を対象として, 構造物に頼らない手法と しての養浜の効果について熊田ら（2007）による粒径を 考慮した等深線変化モデルにより検討する。なお，宇多

1 正会員

2 正会員

3 正会員

4 非会員

5 非会員

6 正会員
国土交通省国土技術政策総合研究所海岸室 国土交通省国土技術政策総合研究所海岸室長 工博（財)土木研究センター常務理事なぎさ総合 研究室長兼日本大学客員教授理工学部海 洋建築工学科 海岸研究室 (有) 福井県土木部砂防海岸課

工修（財）土木研究センターなぎさ総合研究室
ら（2007）でも浜住海岸の海浜変形予測が行われたが, その際計算は展開座標系で行われた。本研究では, 現象 の理解を容易にするために実座標を用いて検討した。具 体的には，地形変化の再現計算を行った上で，九頭竜川 河口と福井港の航路への堆砂をサンドバイパスした場合 や, 埋立地の南側隣接部の前浜砂を浜住海岸にサンドリ サイクルした場合の効果と影響について検討した。

\section{2. 浜住海岸の汀線変化の実態}

空中写真から求めた浜住海岸の汀線変化を図-2に示 す.図-2（a）は自然状態にあった1968年を基準とした汀 線変化を示す。1968年は福井港の埋立地の建設以前であ り, 九頭竜川河口から鷹巣港まで長さ約 $11 \mathrm{~km}$ の砂浜 (三里ケ浜) がほぼ直線状に伸びていた。 その後 1985 年 までに福井港の埋立地が造られた結果，現況と同様北端 は埋立地の護岸で仕切られ, 浜住海岸は約 $4 \mathrm{~km}$ のポケッ トビーチとなった. 埋立地が大きく突出したことにより， その南端部では波の遮蔽域が形成され, 備蓄基地の南側 隅角部では三角形状に汀線が大きく前進し，1995年まで には隅角部で汀線が $170 \mathrm{~m}$ 前進した。また，1995年まで に15基の離岸堤が建設されたために海岸南部では汀線が

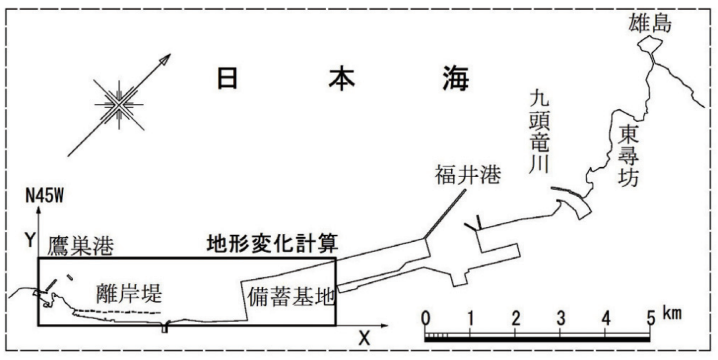

図-1 浜住海岸の位置 
(a) 1968 年基準

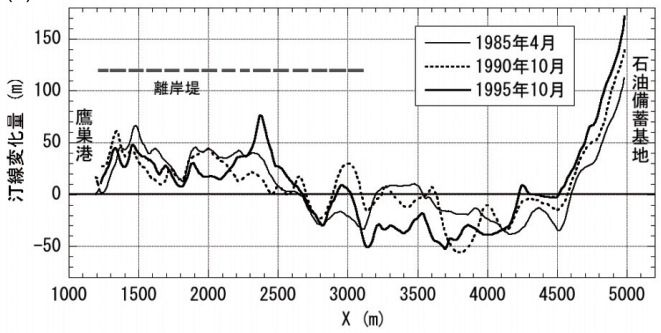

(b) 1995 年基準

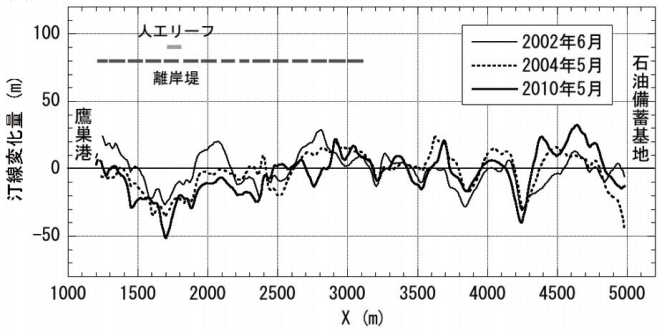

図-2＼cjkstart浜住海岸の汀線変化（1968～2010年）

固定される一方, 離岸堤の北側隣接域の長さ $1900 \mathrm{~m}$ 区間 では汀線が最大 $50 \mathrm{~m}$ 後退した。詳細には浜住海岸の離岸 堤のうち南端から 10 基目までの離岸堤背後では舌状砂州 が安定的に形成されており，これと対照的に 11 号堤から 備蓄基地の南側の $\mathrm{X}=4500 \mathrm{~m}$ までは汀線が凹状に後退して いる. 図-2 (b) は，1995年基準での2010年までの汀線変 化を示す。この間で起きた最も著しい汀線変化は，5号 離岸堤の人工リーフ化に伴い波浪の侵入度が増したため に, 人エリーフとその両側の離岸堤背後の汀線が最大 $17 \mathrm{~m}$ 後退したことである. また, 離岸堤の設置区域と, 離岸堤と備蓄基地の間では汀線の変動量が大きいことも 特徵である.

\section{3. 養浜効果検討の基本的考え方}

地形変化計算に先立ち, 図-1に示したように沿岸方向 に $15 \mathrm{~km}$ ，岸沖方向に $7 \mathrm{~km}$ の矩形領域において不規則波の 方向分散法（酒井ら，2003）を用いて波浪場の推定を行 った。次に, 鷹巣港〜福井港埋立地の $4.0 \mathrm{~km}$ 区間を対象 として粒径を考慮した等深線変化モデルにより海浜変形 計算を行った。この場合 $\mathrm{Y}$ 軸は卓越波向（NW）方向に， またX軸はこれと直角方向に取っている，計算では，ま ず自然状態にあったと考えられる1968年地形を与えて 2007年地形を再現した。2007年までには，鷹巣港防波堤 と福井港の埋立地に石油備蓄基地（以下, 備蓄基地）が 完成し，さらに 15 基の離岸堤が設置されていたが，その 直後 5 号離岸堤の人工リーフ化が行われた。したがって 2007 年は離岸堤の人エリーフ化直前の状況に対応する. さらに 2007 年の計算結果を基に 5 号堤が撤去され, 人工 リーフ化された後の 2010 年地形の再現計算を行った。こ

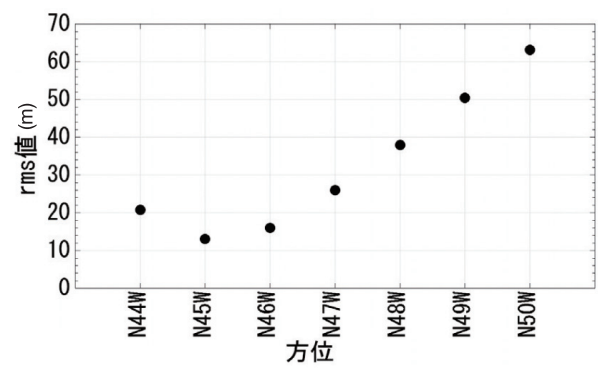

図-3 実測と計算汀線の差の二乗平均值

のような再現計算により海浜変形モデルの浜住海岸への 適用性を確認した後, 養浜土砂の粒径と量を変えて 10 年 後までの予測計算を行った.

養浜土砂の調達については，1985年以前には浜住海岸 と九頭竜川河口とが一続きの砂浜であったことから分か るように, 当海岸の漂砂源は九頭竜川にある. しかし福 井港の防波堤および埋立地建設によって浜住海岸への漂 砂供給が絶たれる一方, 福井港の航路と九頭竜川河口に は過剰な堆砂が起きていることから, これらの地域の土 砂を浚渫して利用する方法について検討した. 一方, 備 蓄基地の南側隣接区域でも過剩な堆砂が起きていること から, その土砂によるサンドリサイクルの効果・影響に ついても検討した.

\section{4. 計算条件}

養浜工の検討では最初に放置案について検討し，それ に続いて福井港の航路, 九頭竜川河口の堆砂を浜住海岸 沖で養浜する案について検討した。養浜案は, 航路堆砂 と河口堆砂に相当する細粒と中粒土砂をそれぞれ $1 \times$ $10^{4} \mathrm{~m}^{3} / \mathrm{yr}$ の割合で養浜する案, 福井県の浚渫実績から航 路浚渫土砂全量を $2.2 \times 10^{4} \mathrm{~m}^{3} / \mathrm{yr}$ で, 河口浚渫土砂を $3.5 \times 10^{4} \mathrm{~m}^{3} / \mathrm{yr}$ で, さらに両者の和を $5.7 \times 10^{4} \mathrm{~m}^{3} / \mathrm{yr}$ の割合 で投入する案を設定した。

波浪条件については, 福井港での観測結果に基づき冬 季のエネルギー平均波として $, \mathrm{H}_{\mathrm{o}}{ }^{\prime}=2.2 \mathrm{~m}, \mathrm{~T}=7.4 \mathrm{~s}$ を与え た。福井港での卓越波向はNWであるが, これを参考と しつつ $\mathrm{N} 44^{\circ} \mathrm{W}$ から $\mathrm{N} 50^{\circ} \mathrm{W}$ まで $1{ }^{\circ}$ 間隔で入射方向を変 化させ, $X=1.1 \mathrm{~km} \sim 4.9 \mathrm{~km}$ 間において 1968 年の実測汀線 形を最もよく表現できる波向を求めた。図-3 は, 上記区 間に扔ける実測と計算汀線の差の二乗平均值を示すが,

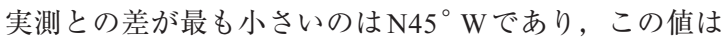
福井港で観測された卓越波向と一致した。 よって以下の 計算ではこの波向を用いた.

漂砂量分布については, 当海岸では粒径が細かい砂で 構成されていることから, 水深方向に一様分布を仮定し た. 本計算は, 様々な粒径の土砂を用いた養浜時の効果 検討を行うために，粒径は3成分からなるとし，それぞ 
表-1 計算条件

\begin{tabular}{|c|c|}
\hline 計算乇 & $\begin{array}{l}\text { 粒径·等深線変化モデル（熊田ら, 2007） } \\
\text { 波浪場：方向分散法（酒井ら,2003） }\end{array}$ \\
\hline 計算対象区域 & $\begin{array}{l}\text { 地形変化計算：7km（鷹巣港～福井港埋立地） } \\
\text { 波浪場の計算 } 15 \mathrm{~km} \text { (鷹巣港～雄島) }\end{array}$ \\
\hline & 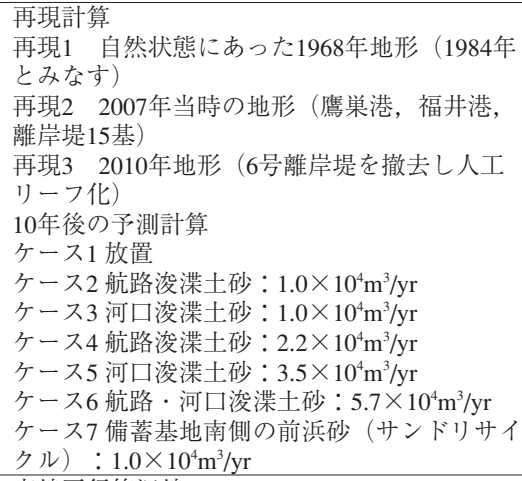 \\
\hline 初期地形 & 直線平行等深線 \\
\hline 入射波条件 & $\begin{array}{l}\mathrm{H}_{\mathrm{o}}{ }^{\prime}=2.2 \mathrm{~m}, \text { 周期 } \mathrm{T}=7.4 \mathrm{~s}, \text { 波向NW（冬期エネル } \\
\text { ギー平均波）， } \mathrm{S}_{\max }=10 \\
\text { 波高の低減率の最小しきい值：0.0, 波の抽出 } \\
\text { 1step毎 }\end{array}$ \\
\hline & M.S.L. $=$ T.P. $\pm 0.0 \mathrm{~m}$ \\
\hline 計算等深線 & $\mathrm{z}=+3 \mathrm{~m} \sim-16 \mathrm{~m}$ \\
\hline 計算メッシュ & 沿岸方向 $\Delta X$ \\
\hline 計算時間間隔 & $\Delta t=5 \mathrm{hr}$ \\
\hline プ数 & $\begin{array}{l}\text { 自然状態 } 3.2 \times 10^{5} \text { step } \\
\text { ※安定形まで }(1752 \text { ステップ／yr) } \\
\text { 将来予測 } 1.752 \times 10^{4} \text { step }\end{array}$ \\
\hline 粒径 & 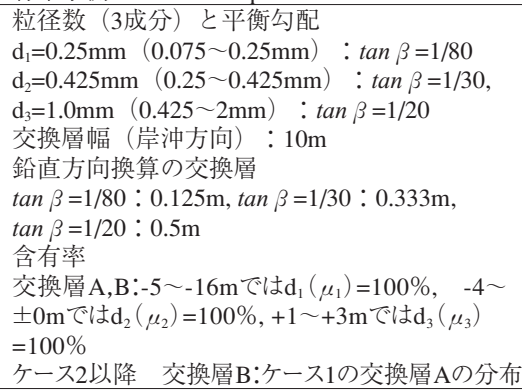 \\
\hline 漂砂量 & $\begin{array}{l}\text { 沿岸漂砂量係数 } K_{x}=A / \text { sqrt }(\mathrm{d}) \\
\text { 係数 } A=0.025 \\
\text { 小笹 } \cdot \text { Brampton係数 }: K_{2}=1.62 K_{x}(\tan \beta=1 / 30) \\
\text { 岸沖漂砂量係数 }: K_{y}=0.2 K_{x} \\
\text { 安息勾配 }: \text { 陸上 } 1 / 2, \text { 水中 } 1 / 2\end{array}$ \\
\hline 漂砂量岸沖分布 & 一様分布 \\
\hline & 岸沖端, 南端, 北端 $\quad q_{y}=0 \mathrm{~m}^{3} / \mathrm{yr}$ \\
\hline 構造物条件 & $\begin{array}{l}\text { 波高伝達率 } \\
\text { 離岸堤 } K_{\mathrm{t}}=0.6 \quad\left(10 \text { 号堤 }: K_{\mathrm{t}}=0.2\right) \\
\text { 鷹巣港 } K_{\mathrm{t}}=0.0 \\
\text { 福井港埋立地 } K_{\mathrm{t}}=0.0 \\
\text { 6号堤のリーフ化 } K_{\mathrm{t}}=0.6 \rightarrow K_{\mathrm{t}}=0.9\end{array}$ \\
\hline 養浜条件 & $\begin{array}{l}\text { 養浜区域 } \mathrm{X}=1.6 \mathrm{~km} \sim 2.0 \mathrm{~km}, \text { 水深 } 6 \sim 8 \mathrm{~m} \\
\text { サンドリサイクの採取区域X=4.6km } 4.9 \mathrm{~km}, \\
\text { 水深 } 0 \sim-2 \mathrm{~m} \\
\text { 養浜材の粒度組成 }\left(\text { シルト }: \mathrm{d}_{1}: \mathrm{d}_{2}: \mathrm{d}_{3}\right) \\
\text { 航路浚渫土砂 }(9.3: 85.9: 4.1: 0.7) \\
\text { 河口浚渫土砂 }(6: 21.7: 39.6: 32.7) \\
\text { サンドリサイクル }(0: 0.1: 5.6: 94.3) \\
\text { ※シルトは流出分として考慮 }\end{array}$ \\
\hline
\end{tabular}

れの代表粒径（平衡勾配）は， $\mathrm{d}_{1}=0.25 \mathrm{~mm} （ \tan \beta=1 / 80 ）$ ， $\mathrm{d}_{2}=0.425 \mathrm{~mm}(\tan \beta=1 / 30), \mathrm{d}_{3}=1.0 \mathrm{~mm} \quad(\tan \beta=1 / 20)$ と した。表-1には種々の計算条件をまとめて示す.

\section{5. 再現計算の結果}

最初に平行等深線地形を設定し, 方向分散法で求めた 波浪を十分長い時間（180年間）作用させ，埋立地造成 前の自然状態にあったと考えられる1968年地形を再現し た。図-4が計算された海底地形を示す。埋立地は存在し ないから端部近傍でも等深線は平行に伸びている。これ に対して鷹巣港側では波の遮蔽効果により湾曲した等深 線形状となっている。図には1968年の実測汀線も重ねて 示すが, 計算と実測汀線はよく一致し, 再現性が高いこ とが分かる.

次に, 1968年地形を与えて 2007 年地形の再現計算を行っ た. 2007 年には鷹巣港, 福井港の埋立地, および 15 基の離 岸堤が完成している。図-5(a) は計算された海底地形を, また 1968 年から 2007 年までの水深変化量を図-5（b）に 示す. 離岸堤群のうち南端部と中央の 10 号堤の背後では 顕著に堆砂が生じるとともに, 福井港の埋立地の隅角部 では著しい堆砂が生じた. 堆積土砂は主に離岸堤群と埋 立地の間の $1.8 \mathrm{~km}$ 間から運ばれたために，この区間では 著しい侵食が生じた。一方, 鷹巣港の沖防波堤による波 の遮蔽効果に伴いその背後域でも堆砂が生じたことが分 かる. 図-5 (c)，（d）には等深線の拡大図と1968年基準で の汀線変化を示す. 図-5 (c) に示すように離岸堤群の北 側では侵食されて窪地が形成されており，そこが汀線後 退区域と一致している。実測汀線は2004年であるのに対 し，計算は 2007 年と 3 年間の差はあるが，各種構造物の 建設後長時間が経過しているので2004～2007年の変化 は少ないと考えられる。これを考慮すると汀線変化はか なりよく一致しているといえる.

図-6 (a)，（b）には5 号離岸堤が人工リーフ化される直 前の 2007 年の海底地形を与えたときの 2010 年の等深線 と水深変化量の平面分布を示す. 離岸堤の人工リーフ化 に伴い開口部からの波浪侵入度が高まったために 5 号堤 の背後で侵食が進んでいる，図-6 (c)，（d）には等深線の

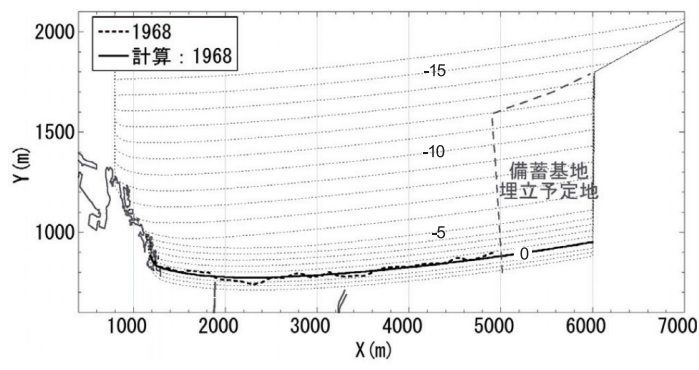

図-4 1968年地形の再現計算結果 


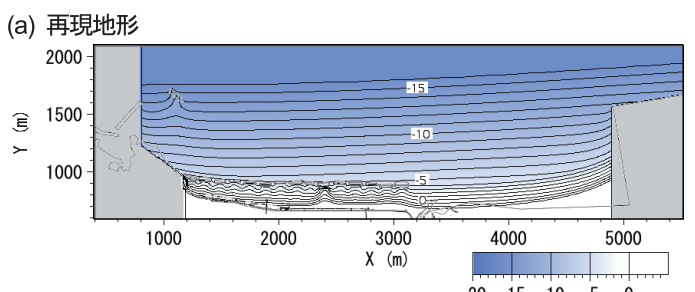

(b) 水深変化量（1968 年基準）

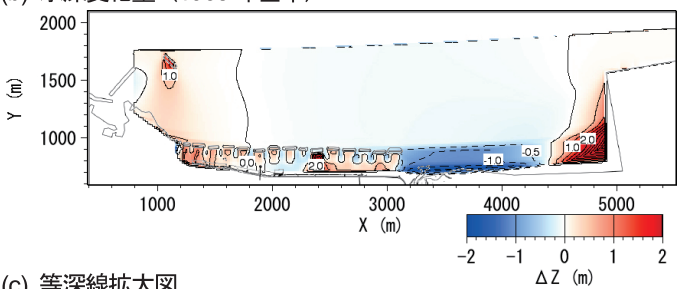

(c) 等深線拡大図

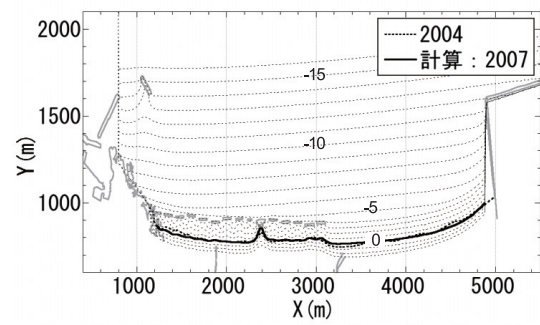

(d) 汀線変化（1968 年基準）

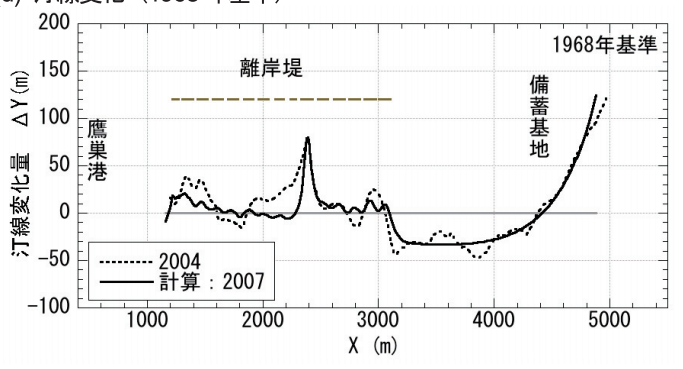

図-5 2007年地形の再現計算結果

拡大図と1968年基準での汀線変化を示す．汀線変化で見 ると離岸堤が人工リーフ化された区域周辺で汀線が後退 したことが分かる.

\section{6. 養浜の効果検討}

同定された海浜変形モデルを用いて養浜の効果検討 を行った。養浜では，いずれのケースに拈いても沿岸 方向に $\mathrm{X}=1.6 \mathrm{~km} \sim 2.0 \mathrm{~m}$ 区間の水深 $6 \sim 8 \mathrm{~m}$ に土砂を投入 した。まず 10 年間放置のケース 1 の地形変化量の分布 を図-7 (a) に，汀線変化を図-8に示す．放置では，5号離 岸堤を人工リーフ化した部分でわずかながら侵食が進 み, 海岸の南端付近で堆積が起こるが, 地形変化量およ び汀線変化量ともに小さい. 航路浚渫土砂を $1 \times 10^{4} \mathrm{~m}^{3} / \mathrm{yr}$

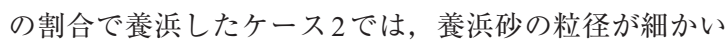
ため投入砂は広く拡散し, 同時に投入量も小さいため汀 (a) 再現地形

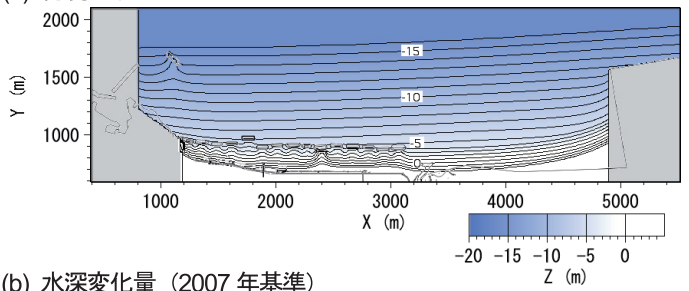

(b) 水深変化量（2007 年基準）
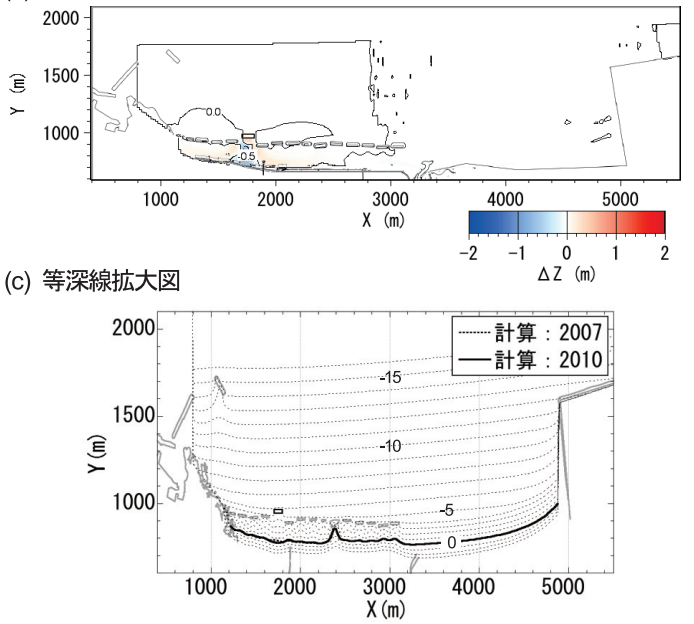

(d) 汀線変化（1968 年基準）

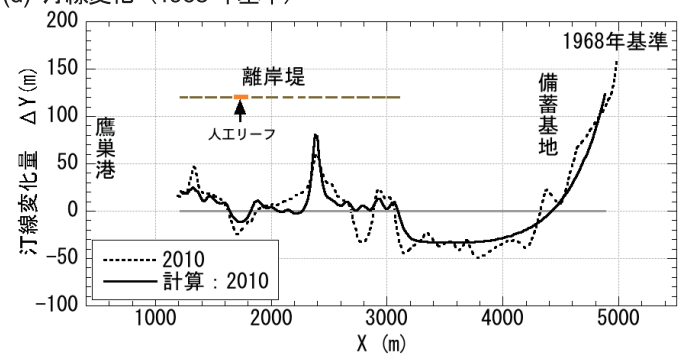

図-6 2010年地形の再現計算結果

線の前進もほとんど見られない (図-7 (b) , 8). しかし河口 浚渫土砂を同量投入したケース 3 では，粒径が相対的に大 きくなったため離岸堤群の岸側での堆砂が著しく，10年間 で最大 $20 \mathrm{~m}$ 汀線の前進を図ることができる（図-7（c）,8). このように河口堆砂は航路浚渫土砂と比べると粒径が相 対的に大きいため, 明らかに養浜効果が出ている. 航路 浚渫土砂を $2.2 \times 10^{4} \mathrm{~m}^{3} / \mathrm{yr}$ の割合で養浜したケース 4 で は，養浜量が増加したにもかかわらず投入土砂は広く拡 散し, 汀線の前進を図ることはできない（図-7（d）, 8). 一方, 河口浚渫土砂を同量養浜したケース 5 では，ケー ス 3 に見られた離岸堤岸側での堆砂がいっそう強調され ており, 相対的に粗な粒径の河口部堆積土砂の養浜材と して有效性が見てとれる（図-7 (e)，8).さらに航路と河 口浚渫土砂の両者の和を $5.7 \times 10^{4} \mathrm{~m}^{3} / \mathrm{yr}$ で投入したケー ス6では, 離岸堤の岸側での集中的な堆砂と, 沖合での 
(a) ケース 1 (放置)

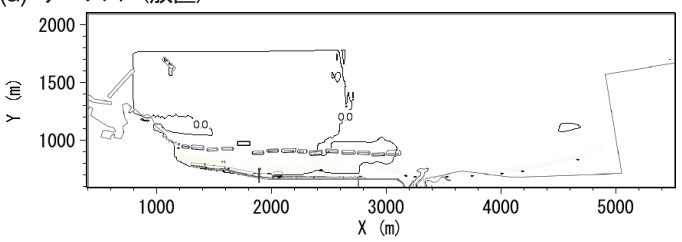

(b) ケース2（航路浚渫土砂 : $1 \times 10^{4} \mathrm{~m}^{3} / \mathrm{yr}$ )

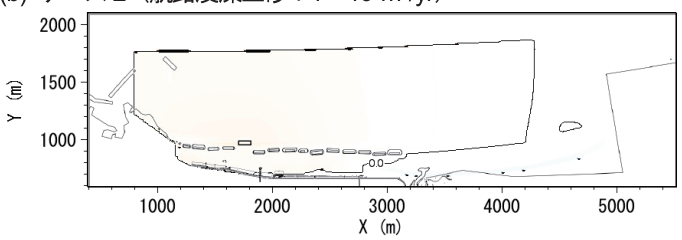

(c) ケース 3 (河口浚渫土砂 : $1 \times 10^{4} \mathrm{~m}^{3} / \mathrm{yr}$ )

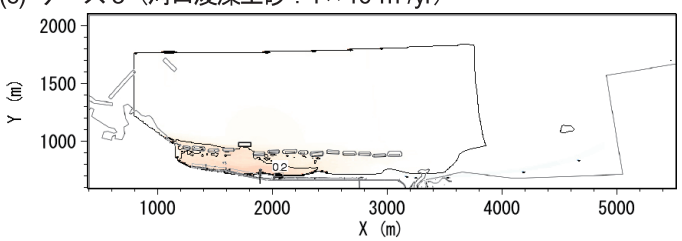

(d) ケース4（航路浚渫土砂 : $2.2 \times 10^{4} \mathrm{~m}^{3} / \mathrm{yr}$ )

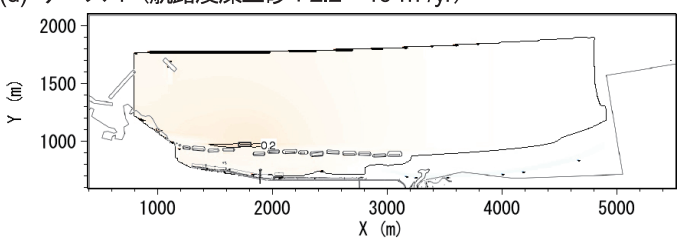

(e) ケース 5 (河口浚渫土砂 : $3.5 \times 10^{4} \mathrm{~m}^{3} / \mathrm{yr}$ )

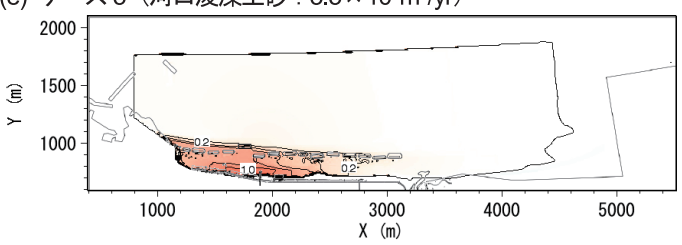

(f) ケース6 (航路 · 河口浚渫土砂 : $5.7 \times 10^{4} \mathrm{~m}^{3} / \mathrm{yr}$ )

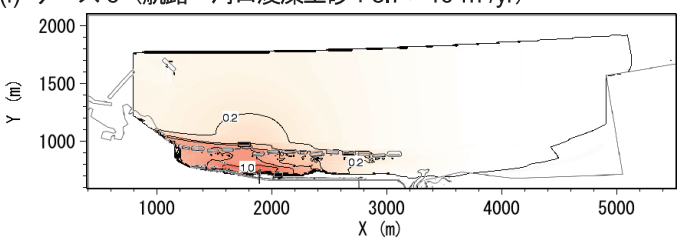

(g) ケース7 (サンドリサイクル : $1 \times 10^{4} \mathrm{~m}^{3} / \mathrm{yr}$ )

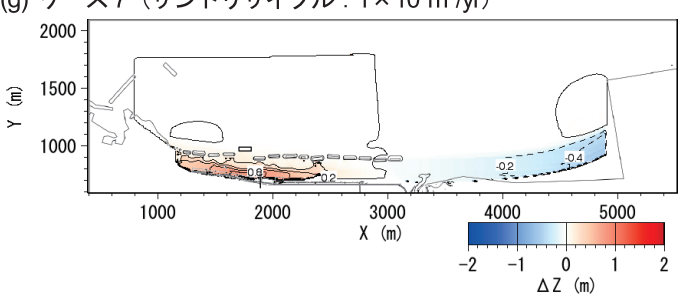

図-7 2010年地形の再現計算結果

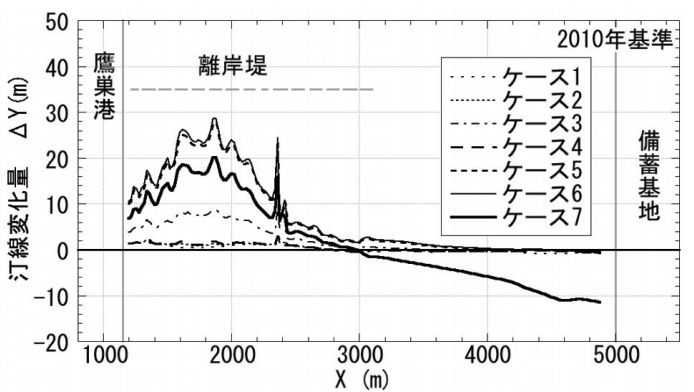

図-8 汀線変化量の比較 $($ ケース $1 \sim 7)$

緩やかな堆積が同時に起こる（図-7 (f)，8)。汀線前進量 はケース5の場合と同じであることから，汀線前進を図 るには粒径が相対的に大きい河口浚渫土砂が有効であ り，また沖合での緩やかな堆積を期待するのであれば航 路浚渫土砂による養浜が有効である。最後に，備蓄基地 の南側隣接部の堆積域から $1 \times 10^{4} \mathrm{~m}^{3} / \mathrm{yr}$ の割合で砂を採取 し，南部で養浜するケース7では，他のケースと異なり 過剩に砂が堆積している部分では汀線が最大 $10 \mathrm{~m}$ 後退す るが，南部の離岸堤背後では汀線を $10 〜 15 \mathrm{~m}$ 前進させる ことができる (図-7 $(\mathrm{g}), 8)$.

\section{7. まとめ}

福井県浜住海岸を対象として, 福井港の埋立地と鷹巣 港の防波堤，さらには浜住海岸における 15 基の離岸堤建 設に伴って生じた地形変化を，粒径を考慮した等深線変 化モデルを用いて再現した。 さらに同定されたモデルを 用いて, 福井港の航路浚渫土砂と河口浚渫土砂を用いた サンドバイパスの効果検討を行った。また埋立地南側隣 接部の堆積土砂を用いたサンドリサイクルの効果検討も 行った。この結果, 浜住海岸の離岸堤背後の汀線前進の ためには九頭竜川河口の浚渫土砂が有効なこと，一方， 福井港の航路浚渫土砂は粒径が相対的に小さいため汀線 前進には効果的でないが, 離岸堤沖の海底地盤の底上げ には役立つことが分かった。またサンドリサイクルも浜 住海岸の前浜拡大に有効なことも明らかになった。

\section{参 考 文 献}

宇多高明・山本 学・ 三波俊郎 - 古池 鋼 - 星上幸良・石川 仁憲（2007）：福井県浜住海岸の侵食実態と離岸堤群の 漂砂制御効果, 海岸工学論文集, 第 54卷, pp. 561-565.

熊田貴之・宇多高明・芹沢真澄（2007）：卓越精径集団に応 じた平衡勾配を考慮した等深線・粒径変化モデル, 土木学 会論文集 B, Vol. 63, No. 2, pp. 154-167.

酒井和也一小林昭男 - 宇多高明 - 芹沢真澄 - 熊田貴之 （2003）：波の遮蔽構造物を有する海岸における3次元静 的安定海浜形状の簡易予測モデル, 海岸工学論文集, 第 50 卷, pp. 496-500. 